\title{
Stress Management for the Owner of Private Health Care in Bandung During PSBB
}

\author{
(Field Study in Cikutra Sehat Pratama Clinic)
}

\author{
Caroline Halim* \\ Master of Management \\ Universitas Islam Hospital Bandung \\ Bandung, Indonesia \\ *aet_ok@yahoo.com
}

\begin{abstract}
The outbreak of COVID-19 in Indonesia has made some significant adjustments in our communities, without exception of the service in Pratama Clinic. Our government also implements some PSBB policies that certainly initiate the limit of the citizens' activities. The people are advised to stay inside home, yet the health workers and clinics' owners are obliged to stay outside their homes, surely due to the commitment to the others. The regulations of PSBB urge the alteration in the service protocol in Pratama Clinic, therefore these worry the clinic owners and force them to get along with this immediately, moreover it could possibly cause stress to the owners. Unexpectedly, this kind of protocol spends more expenses as well. Surely, the owners have to provide utmost protection for the workers and insure the staff stay in health condition during these difficult times. The research was conducted in Cikutra Sehat Pratama Clinic Bandung, not only by observation method but also by interviewing the owner. Both methods are aimed to figure out whether by applying the stress management, the owner would not be anxious and free from distress during this pandemic situation. This study concludes that the stress management enables the owner to get through the hardship during PSBB.
\end{abstract}

Keywords-stress management, Pembatasan Sosial Berskala Besar (PSBB)

\section{INTRODUCTION}

It cannot be denied that the Corona pandemic has come in Indonesia in March 2020. As a result of this Covid-19 virus, changes have occurred in our society. To accelerate the controlling of Covid 19 cases, the government has enacted the Large-Scale Social Restriction (PSBB), which means that every citizen is urged to stay at home, work from home, study from home, even worship also at home [1].

In the course of the PSBB, there are only a few public facilities allowed to operate, such as: supermarkets, markets, pharmacies and clinics [2]. During the Covid-19 pandemic, when all the necessities at the Primary Clinic have changed, the habits of health workers are also required to have some adjustment that occur almost every day causing out-of-budget expenses that have been previously set. This issue initiates anxiety and worry for the owner of Pratama clinic.

At the time of the implementation of the PSBB, there were many provisions that had to be done by clinics, such as: providing PPE for health workers and other workers [3]; merely to serve $30 \%$ patients of the clinic capacity; avoid crowd in the waiting room; and also patients and deliverymen had to wear masks [4].

Prior to fallings into stress, usually people will go through some stages. These stages are called as the stages of grief over the loss or the theory of the stages of grief from Dr. KüblerRoss [5].

This theory describes the feelings of people who have undergone some loss, including losing their job, their beloved person's death, or their income.

The stages are:

- Shock and denial: this feeling will appear primarily and it could be considered as a normal feeling, because typically people will not be certain of and get shocked at what is happening at the present time. We are also hard to accept as true that all of a sudden, we are forced to implement the PSBB, along with timidity why this pandemic happens.

- Anger (Anger): Following the denial stages, there will be anger, resentment towards the present situation. People have to face the fact that they must inevitably follow health protocols.

- Bargaining (Bargaining): Once the anger starts to subside, people will start negotiating over the situation. People can even bargain with God so that they can get away from this situation.

- Depression (depression): As soon as the emotions settle down, people begin to see the fact that it is a reality that they have to face, they start on feeling depressed. 
- Acceptance (Acceptance): On this stage, even though people have to accept the fact, yet they are still in the very sad mood.

Afterwards, it can restart to the early stage, denial, so the above stages are like a continuous circle. Nevertheless, the above stages are not the same for everyone, depending on how each person is.

Stress is like a double-edged sword, because the stress could push some people to conquer the situation so that those particular people became more productive, but if it is not done with proper stress management, it could make people more depressed or weak both physically and mentally [6].

One of the stressors is a work problem because people generally spend most of their day in the working place; furthermore, not having a permanent job, or working with a lot of pressure and stressful environment will cause worse effects. Stress that occurs because of the tension in the workplace could lead to some illness [7]. Stressors in the workplace can also occur due to conflicts among health workers and infrequency of communication among them. Facing cases of Covid-19 indirectly makes the health workers serve in pressure, because they had to be aware of the distance among the patients. Assuredly, this makes restrictions of movement for them. In addition, they must keep on providing the best service to the community, on the other hand, the fear of being infected and risk their family is bothered them as well. This reason initiates the clinic owners to pay a number of additional costs such as preparing PPE for health workers, providing vitamins, and additional healthy food so that health workers could do their job tranquilly. The burden that is directly faced by the clinic owner is the anxiety of the possibility of infected health workers, even worse is the death. Not only does the infection thought become the consideration, but the decreased number of the patients during PSBB period also becomes the burden. Most patients were afraid that if they went to the clinic they would possibly be infected and a demand from the government to stay at home urged them to do so, meanwhile the clinic must keep running and operating. The appeals of social distancing from the government, compelling the clinics to limit the number of patients, and more appeals from the authority oblige the owners to alter regulations almost every day, this is a stressor for clinic owners.

\section{RESEARCH METHODS}

This research article was created with the method of descriptive qualitative observation and direct interviews with the owner of the Cikutra Sehat Bandung. The research was conducted in August 2020. The author chose this method to figure out how the clinic owner could manage stress management for himself when there was pressure in his clinic regarding PSBB.

\section{DISCUSSION}

The reactions that occur in every person is different. Due to that, the symptoms of each person are different. The continuous stress response may cause symptoms that are apparent on the body, both physically and emotionally. Signs and symptoms of stress that can affect behaviours and mood in general include:

- Always restless.

- Quick offended.

- Often sad for no apparent reason.

- Always feeling tense.

- Not confident.

- Feeling alone even in a crowded place.

- Withdrawing from associations.

- Continue to feel uncomfortable.

General Adaptation Syndrome describes the time when a person has a condition that threaten him, then a self-defence mechanism (defence mechanism) in the body is activated. Adrenalin glands of the body produces a number of cortisone and the other hormones which coordinate changes in the central nervous system resulting in an increased heart rate. If the stressor prolongs, it causes the body's organs to not be able to operate adequately. This stage is characterized by a continuously high heart rate, and blood pressure that remains high as well. If the stressor remains and people are not able adapt, then people will be physically and mentally exhausted, and of course it led to depression.

\section{A. Stress Management Methods}

1) Find out what makes us stressed: List down some lists that trigger our stress, then observe what changes we feel and disturb the most, both physically and mentally. How we react over this stress, so that the stress does not interfere our activities

2) Avoid dealing with stress in these following ways:

- Smoking

- Using a sedative pill

- Drink some alcoholic beverages

- Get plenty of sleep

- Fast Food

- Run away from problems

- Playing games without considering the time

- H. Being alone for a long time

3) Keep moving: Keep exercising because during exercise, the body releases endorphin hormones, which are the happy hormones. It can be jogging, taking a leisure walk in an open space or in a park that is not too crowded by using masks and doing health protection. 
4) Keep interacting with other people: Keep interacting with friends by means of WA, video calls, or Zoom.

5) Implement 4a (Avoid, Alter, Adapt, Accept):

- Avoid: avoid thinking unceasingly about things that make you stress

- Alter (change): change our response when stress occurs

- Accept (accept): if the situation continues, we must accept

- Adapt (adapt): must be able to adapt

6) Find time for yourself: When we are in a quiet place, we can do all the things that are fun for ourselves without being afraid that we will be disturbed by our activities.

7) Get closer to the creator: By praying, we can surrender all our life struggles. We can pray anywhere, not limited by place and time. Besides that, we must always be grateful in all things and in all situations.

Stress management is carried out by the owner of the Cikutra Sehat Clinic by identifying the biggest sources of stress, then resolving them wisely, and lastly maintaining good communication with health workers, so that the health workers desire and the provisions of the government could be done well. Moreover, the clinic owners also do not smoke and drink alcoholic beverages. Conducting some changes in the clinic, such as a request for patient escorts to be limited to only one person, and for patients who are fever, they have to do an immediate report when registering so that while waiting, they could be separated from other patients. Another demand is social distancing and masks-wearing patients and deliverymen. The patients are informed about the time of their examination, so that if the queue is still long, the patient is expected to wait at home. This ensures both the patient and the health worker feel safe.

\section{CONCLUSION}

In facing the Covid-19 pandemic, the owner of the Cikutra Sehat Clinic has carried out stress management independently, even though he is required to do several new health protocols in the clinic but he has managed the stress well by recognizing what becomes the source of stress and not constantly thinking about the source of the stress. As a result, the owner of the clinic has passed through the stress by doing things he likes.

\section{REFERENCES}

[1] Minister of Health, Decree of the Minister of Health Number HK. 01 Menkes/289/2020 [Online]. Retrieved from: Jakarta Source: https://setkab.go.id/penerapan-psbb-provinsi-jawa-baratdis Agreed-menkes/, 2020.

[2] S. Bahfein, The following is a list of public facilities that are allowed to open during the PSBB. Jakarta.Kompas.com, 2020.

[3] W. Widyawati, Levels of PPE for Medical Workers when Handling Covid-19. Jakarta: Healthy Editors Negriku, 2020.

[4] WHO, Now Supports Everyone to Wear Masks to Prevent Covid-19. CNN Indonesia, 2020

[5] R. Saraswati, The 5 Stages of Grief and How to Get Through It . Jakarta: Healthy Editors Negriku, 2020.

[6] A. Pongtiku, Double-edged Sword Stress in the Covid-19 Period. Papua Rises, 2020.

[7] C. Wade and C. Tavris, Psychology. Jakarta: Erlangga, 2007. 